\title{
Borges and Photography
}

David WILLIAM FOSTER / Arizona State University

\begin{abstract}
Borges is unquestionably the most photographed Argentine author. As someone who assumed something of an international celebrity status before he was widely accepted in his native country, the photographic images of Borges, which outside Argentina quickly went from newsprint to book jackets to gallery walls, were less the consequence in Argentina of any canonical role in national letters than they were the attention of local artists to their acquaintances and associates in rather closed circles.
\end{abstract}

\section{Key Words:}

Camera, Literature, Image, Photography.

\section{Resumen}

Borges es indudablemente el autor argentino más fotografiado de todos los tiempos. Fue alguien que llegó a tener un perfil de celebridad internacional antes de que fuera reconocido en su propio país. Las imágenes fotográficas de Borges fuera de la Argentina pasaron rápidamente de tapas de revista a paredes de galería. Y en la Argentina, estas imágenes se debían menos a su papel canónico en las letras nacionales que a la atención de parte de los artistas nacionales y sus congéneres de círculos relativamente cerrados de amigos íntimos.

Sin embargo, con la enorme importancia que Borges ha cobrado hoy en día para los estudios latinoamericanos e internacionales, este dossier fotográfico, al que complementan imágenes realizadas por fotógrafos no argentinos tras su alcance de una fama internacional, es significativo para entender el rol de la fotografía en los estudios culturales latinoamericanos, especialmente en lo que a figuras literarias respecta. La figura de Borges es vista 
por la cámara en una forma consonante con la evolución de su papel en las letras argentinas, el que va del de un diletante marginal, del no ganador excéntrico y perenne del Premio Nóbel, al del escritor más meritorio de lengua castellana.

\section{Palabras clave:}

cámara, literatura, imagen, fotografía.

Borges is unquestionably the most photographed Argentine author. As someone who assumed something of an international celebrity status before he was widely accepted in his native country, the photographic images of Borges, which outside Argentina quickly went from newsprint to book jackets to gallery walls, were less the consequence in Argentina of any canonical role in national letters than they were the attention of local artists to their acquaintances and associates in rather closed circles. Borges may get some newsprint coverage, before he becomes a hometown celebrity in the 1980s just before his death, when he makes outrageous statements, such as his defense of censorship at the time of the 1967 Bomarzo scandal, when Alberto Ginestera's opera based on Manuel Mujica Láinez novel is banned at the Colón as obscene, or, previously, his confrontations early on in the first Perón administration in the mid-1940s. However, there is little photographic record associated with his career simply as a writer, not even as part of the cover copy of his books, since it has only been in the recent years that Argentine publishers have included a photograph of the author as part of a book's packaging.

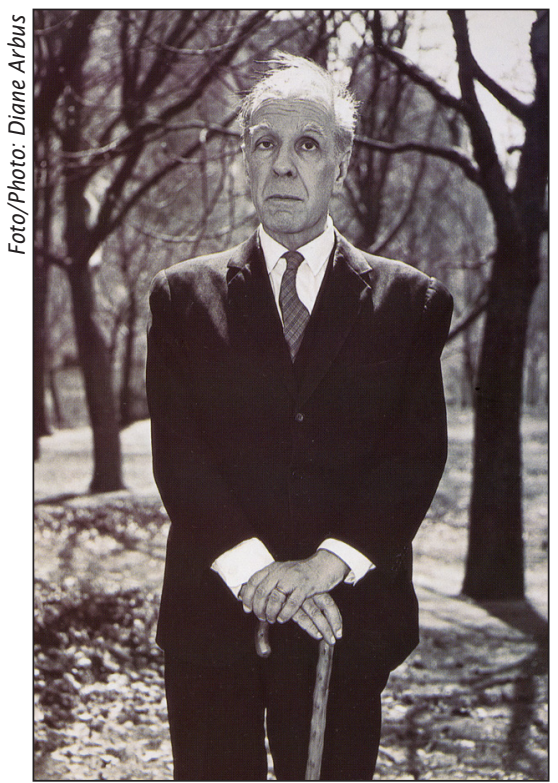

Figura 1.
Photography on Borges can serve teaching interests in a number of ways. It is fundamentally important as part of a record of his life and times, in the mode of the photoraph itself and its semiotics and in the contextualization provided by both the artistic career of the photographer and the grouping of this subject with others. Such images can be studied for their use in illustrating texts dealing with Borges: thse that are hagiographic, those that are denunciatory, and those that are exercises in critical interpretation. Literary journalism, despite its enormous importance in Argentina, has been little studied, and how literary journalism, which early developed the use of caricature and then photography as part of 
a unified text, has dealt with Borges is concomitant with how Borges has been shown to readers. Another under-examined aspect of Argentine culture production is the book trade, which includes important marketing dimensions, including the all-important Buenos Aires Feria del Libro. How Borges has been marketed is an important entrée into the Argentine book trade. Equally important is how Borges has been marketed internationally, which may or may not coincide neatly with how he has been examined critically (which may involve, all too frequently, not even bothering to take note of his Argentine identity).

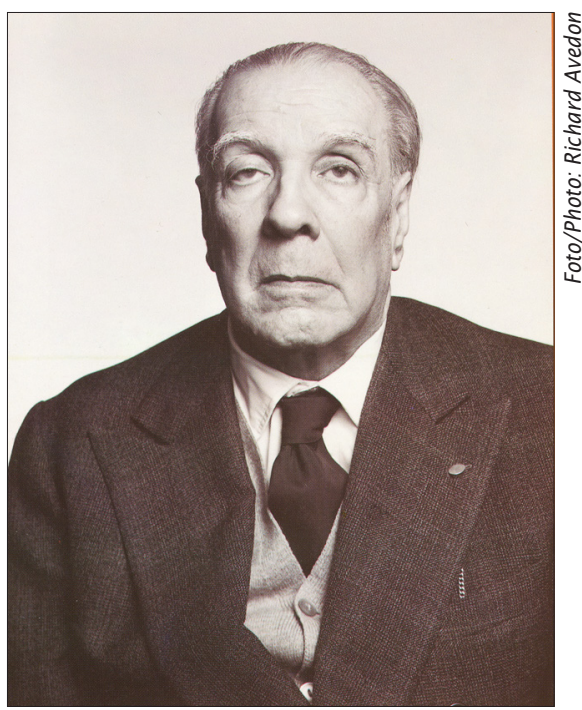

Figura 2.

Yet I would suggest that the most important academic dimension of the photography on Borges would be to use this notable writer, whose distinctive image lent itself so well to both artistic and journalistic projects, as a way of bringing photography into the realm of Latin American cultural studies. While a modicum of attention has been paid to some photographers -Mexico's Graciela Iturbide, Chile's Paz Errázuriz, Brazil's Sebastião Salgado-and some topics have been widely studied via the photographic essays-the Cuban revolution, Brazilian carnival-Latin American photography is simply not on the map of academic studies, not in Argentina, ${ }^{1}$ not in Latin America, and not internationally. ${ }^{2}$ An interest in how Borges has been photographed would be one significant way of discussing photography as a cultural genre in Argentina ${ }^{3}$ and Latin America: in addition to how an attention to that cultural genre has portrayed Borges would be how photography is integral to the whole array of cultural production since the inception of the genre. ${ }^{4}$ Concmitantly, it is important to note that, as the fame of an author grows, the amount of

\footnotetext{
1 See, however, Foster, Argentine Urban Photography.

2 See, however, the groundbreaking survey Images and Memory.

${ }^{3}$ Buenos Aires hosts every August the international event, Festival de la Luz Argentina, in which hundreds of photographers from all over Latin America and from abroad are represented.

${ }^{4}$ The discovery of Claude Lévi Strauss's Brazilian photographs allows for them to be a part of the record regarding his professional experiences in that country, and it now makes little sense to read a founding text like Tristes tropiques without consulting them. Saudades do Brasil is mainly the "photographic notes" (as he called them) that Lévi-Strauss made while conducting his anthropological fieldwork. Saudades de São Paulo is a parallel collection of his images taken while residing in that city during and immediately after his involvement in the early faculty of the Universidade de São Paulo. Foster, "Saudades do Brasil" examines Lévi-Strauss's photographic work.
} 


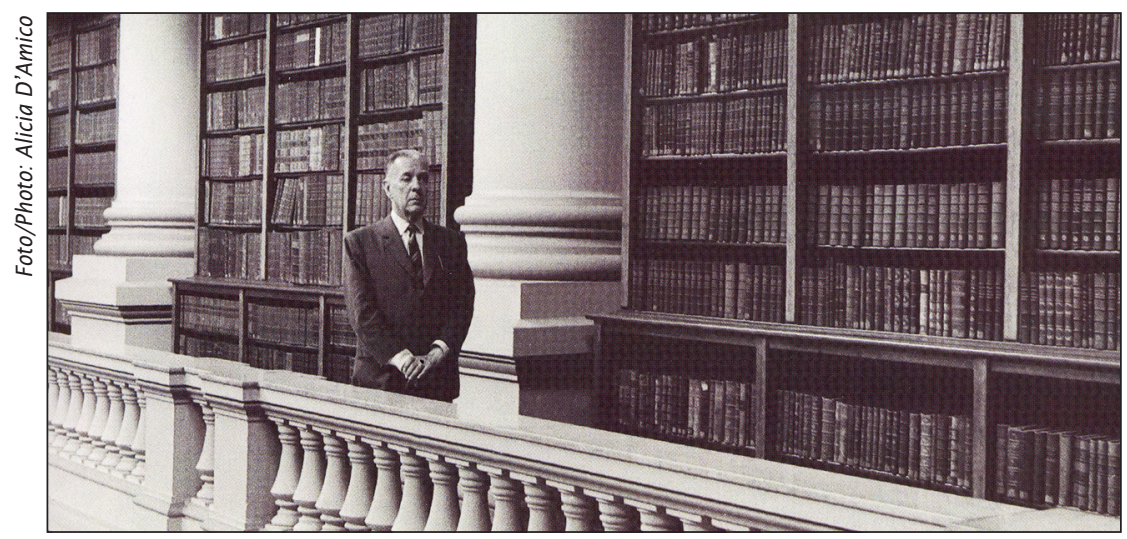

Figura 3.

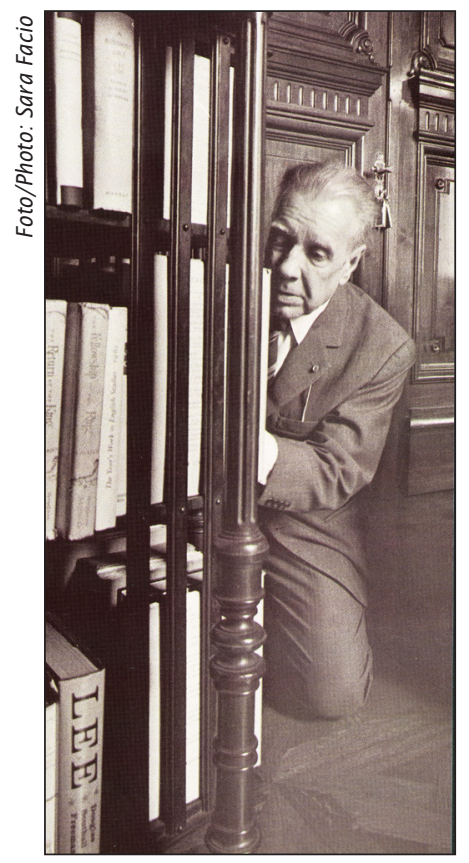

Figura 4.

photographic attention in increases: there is a direct proportion between the photographic record and public esteem, as the photographs are used to illustrate the coverage of important events such as prizes, interviews and critical commentaries (mass-market as well as academic), professional activies, the design of published books, and advertising campaigns. Photographs are not neutral adornments, but are customarily integral to the way in which an author is viewed by the photographer, which may, in turn, be the consequence of the way in which the photographer perceives how the author is viewed by the public. Just as the illustrations accompanying a text constitute both an interpretation on the part of the artist and the inducement by the artist for the reader to entertain a particular interpretation, photographs of the artist serve as part of the overall semiotic bundle that is the text.

Photographs of Borges might, then, be viewed in three intersecting categories: 1) Borges as a personality of a vanguard literary set; 2) Borges as international figure; and 3) the aging Borges, now-finally-a national icon, complete with his own street, cultural center, and museum, along with other attributes. ${ }^{5}$ Were one to

\footnotetext{
${ }^{5}$ These three categories are chronological. Another cut might be in terms of subject, such as Borges writing, Borges speaking, Borges at the Biblioteca Nacional. Undoubtedly one of the most engaging of thematic groupings would be Borges and his family and friends, especially Borges and his mother,
} 
have a registry of Borges photographs, it might be possible to discern other groups: perhaps one ought to speak of the photographs that accompany denunciatory texts, such as the articles regarding his comments on the Bomarzo affair, ${ }^{6}$ although far more interesting is the parallel bibliography of Borges caricatures, the vast majority at his expense. ${ }^{7}$

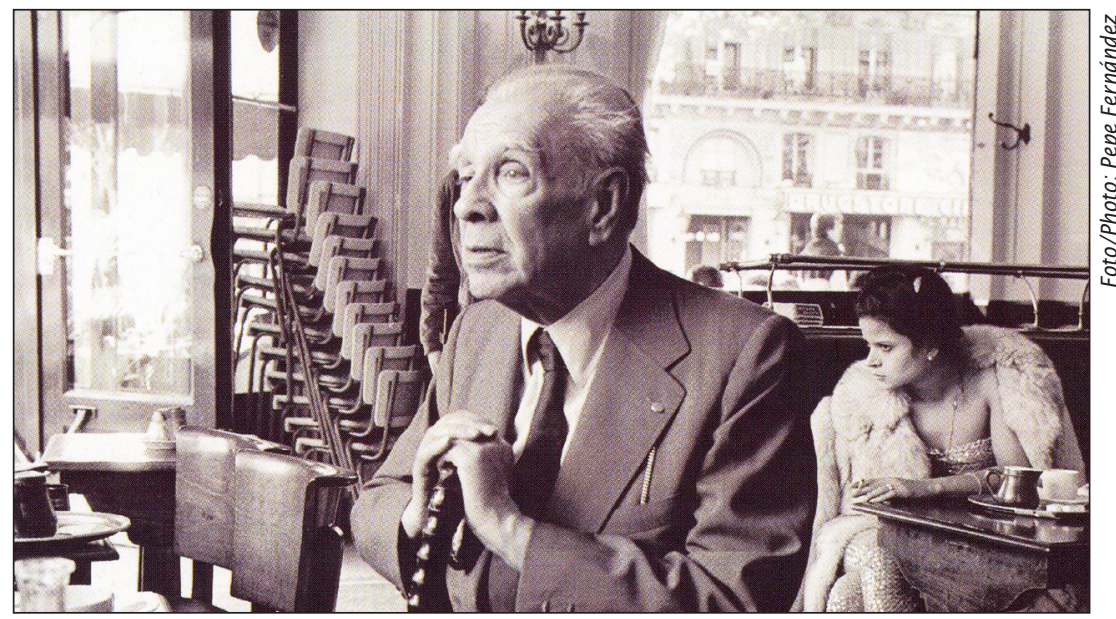

Figura 5.

Some of the most important photographers in Argentina at the time of the so-called vanguard movement were women and many of them were European (some in flight from the rise of fascism). These are the authors of the first major images of Borges.

Greta Stern (1904-99) is generally considered the apex of this group. $8 \mathrm{Her}$ iconographic photograph of Borges as writer-intellectual dates from 1951 before Borges began to lose any use of his sight. For this reason, one of the singular characteristic of the photograph is that Borges looks straight at the camera, and the reflections of the lights can be seen in his irises (Stern 31).

which would necessarily include the famous photograph of the two of them, with Leonor Acevedo striking a quite coquettish pose, at the University of Texas in 1961.

${ }^{6}$ It is entertaining to think of what sorts of photographs might accompany Juan Fló's Contra Borges, a collection of essays deriding Borges.

${ }^{7}$ A survey of such material would include humor magazines like the extremely important Humor registrado. Perhaps one of the most important such efforts, because of the artistic stature of the artist, is the dossier devoted exclusively to Borges, Georgie, Dear by the Uruguayan Hermenegildo Sábat. "Ceorgie" was Borges's Anglophile family nickname, but it was generally used scornfully by his detractors, as represented by Adolfo Prieto's 1954 clarion call of derision, Borges y la nueva generación (for analysis of Prieto's work, see Foster). Sábat's images were published by Editorial Crisis, the publishing house of the one of the most important stridently anti-Borges publications, the review Ideas, letras, artes en la crisis (1973-76?).

${ }^{8}$ See Foster, "Dreaming in Feminine" for an analysis of Stern's most influential project, the Sueños. 


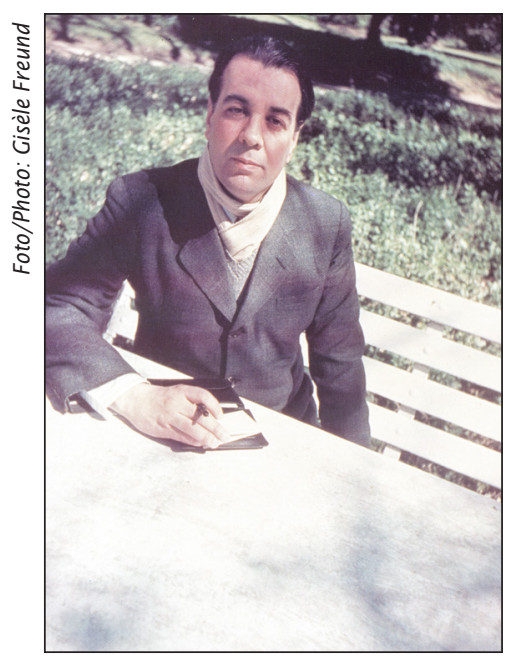

Figura 6.
Seated on a worked-wooden chair (of the sort typically found, even today, in the cafés that Borges and his set frequented), his arms resting on his knees, Borges leans slightly forward, with a gentle and benign smile, as though ready to engage in conversation. That this conversation is likely to be high-toned is indicated by the metonymic presence of a pair of reading glass that he holds folded in his hands, each hand clasping one end of the frame. Borges seems to have been rarely photographed wearing glasses, perhaps because of the complex and intense array of lights used at the time by portrait photographers like Stern. Borges is dressed in the typical "uniform" of the French intellectual that dominated in Argentina until it was replaced in the late 1960s by the penchant of the left for blue jeans. Eschewing the rigorously English suit of the Argentine man of political and economic influence, Borges wears a pair of plain wool pants and a non-matching wool jacket, with a white shirt and tie. ${ }^{9}$

Stern's photograph was taken at a time when Borges was deeply embroiled in controversy. He had alienated the Peronista right by his denunciations of them as populist rabble, and he had been declared as a frivolous and irrelevant writer by ledt. Public images of him were hardly flattering, and Stern's approach is to provide a an image of tranquil humanity.

Equally influential in her work as a photographic portraiturist was Stern's fellow German (but not Jewish), Annemarie Heinrich (1912-2005). Heinrich is probably best know for her publicity work with film stars from Argentina's Golden Age of the 1930s and 1940s, although she also did extensively fashion photography for publications like Paris Vogue. ${ }^{10}$ One of her major subjects of this period was the young Eva Duarte and her 1944 portrait of Evita is perhaps the most famous image of that rising female personality. ${ }^{11}$

\footnotetext{
${ }^{9}$ Another iconic photograph of Borges the writer is that of Gisèle Freund [Tribute 38]. Freund (19082000) was French (and Jewish) and worked less time in Argentina than Stern and Heinrich; she too was renowned for her work with Evita, her dossier of photographs of the now Sra. Perón appearing in the December 11, 1950 issue of Life magazine.

${ }^{10}$ In addition to her fashion and publicity photography, Heinrich did much artistic work with women, including many nudes. There is a pronounced lesbian dimension to much of this work, and some images even provoked scandals (see Foster, "Annemarie Heinrich").
}

${ }^{11}$ Because of her extensive work with the future Sra. Perón, after Evita's death in 1952, Perón demanded that Heinrich turn over her entire Evita archive: this was the most notorious intersection 
Heinrich's image of Borges dates from 1966 , after his consecration as a writer of international stature and at a time when his physical infirmities were much in evidence (Heinrich 91). It is also the year when an authoritarian military regime comes to power, a harbinger of the open neofascism of the next decade. And it is when Borges will become infamous for his support of the military regime, which has as its major agenda the definitive quashing of the lingering Peronista period, which really did not end with Perón's overthrow by the military in 1955. Concomitantly,

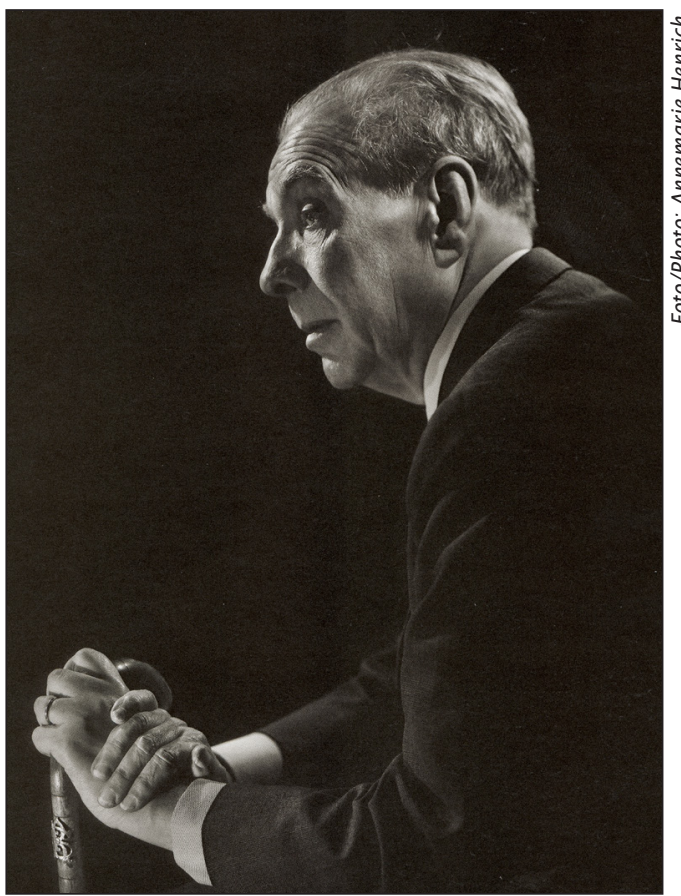

Figura 7

Borges received preferential treatment by the immediate cultural apparatus of the dictatorship and its defenders throughout Argentine society; this is the period when Borges began to receive extensive journalistic coverage and to be much photographed by the media. His 1967 marriage was treated by the press as a celebrity event.

Heinrich's photograph, then, reveals an aging Borges. This time he wears the upper-class uniform of a finely texture suit and expensive shirt. Now somewhat stooped, Borges rests his hands on an elaborately detailed cane. Now legally blind, it would be unacceptable-at lest for the sort of artistic photography in which Heinrich engaged, all subtle shadings and soft lines - to have Borges looking directly in the camera, although other photographers will undertake to capture the visage of the blind Borges (Julio Guistozzi, for example [Tribute 39]). Borges's face, thus, is turned away from the camera and there is somewhat of a vacant, unfocused look on his face, as though the work of the camera were to capture the withdrawal from the outside world that characterizes much of Borges's life from this point on, a consequence of which is that so many of the photographs of Borges

between Argentine photography and Peronista politics. 
during the final twenty years of his life show him accompanied by others, mostly women, that are necessary for his physical wellbeing: the most famous of these companions is his second wife, María Kodama. ${ }^{12}$ Heinrich's image is very much that of the distinguished elder statesman of letter. And Heinrich's use of a black background, where Borges's body, dressed as it is in a dark business suit, fades into the background and bleeds off the right margin. This disappearing effect is complemented by the large mass of black space on the mid- and upper-left-hand side of the photograph, such that the image is dominated only by Borges's head and his hands (the right hand bearing a gold band on the left hand, although the photograph antedates Borges's marriage to Asteta Millán 13). The overall effect affords Borges somewhat of an ethereal, otherwordly quality, in line with standard interpretations of his works at the time: Borges the philosopher of Uqbar, as well as Borges the self-absorbed literary gamesman.

Perhaps the photographer who has most worked with Borges is Sara Facio (b. 1932), now considered, as Heinrich was in her day, the grande dame of the camera in Argentina. Facio worked closely in her first adulthood with Alicia D'Amico (1933-2001), who also photographed Borges, but it is Facio's work with Borges that is central other own outstanding portraitures, although she has yet to publish a volume featuring her most famous subject (Foster, "Sara Facio"). Of these images, the one that I wish to focus on here falls between Stern's and Heinrich's images: it dates from 1964 and features Borges at the

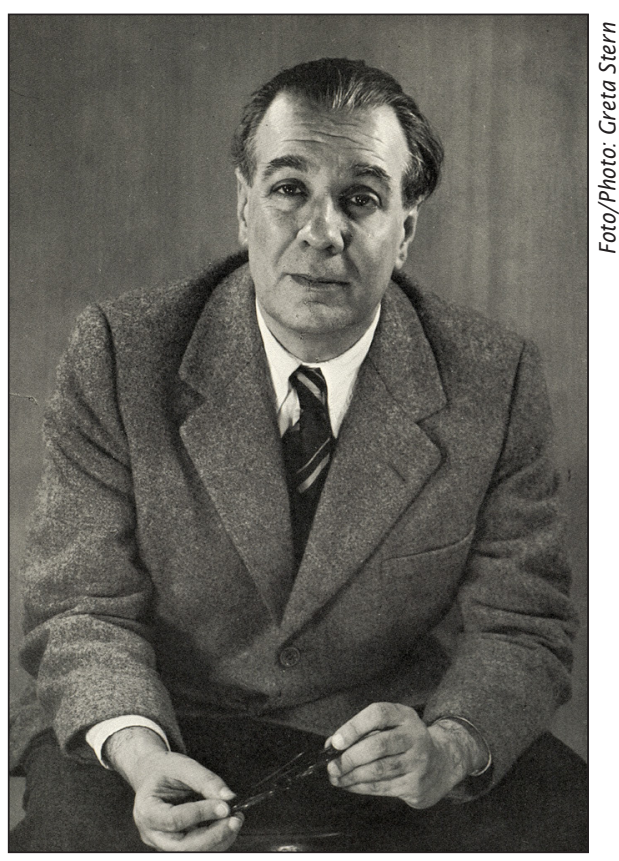

Figura 8.

\footnotetext{
12 Whereas the images of Borges and his mother suggest his emotional dependence on her, those of him and his first wife, Elsa Asteta Millán, reveal the way in which she imposed herself on his life, and those of Borges with Kodoma transmit a sense of the sincere affective bond between them.

${ }^{13}$ This detail is important, because Borges's marriages have always been viewed as quite anomalous: he is the one recurring male personality of these photographers who does not consistently signal his participation in the Argentine establishment by sporting a wedding band. It should be noted that there is much variation in Argentina as regards which hand the band is worn on. Common belief is that, worn on the left hand, it signals a Church wedding.
} 
Biblioteca Nacional (Facio 20). There are several Facio photographs of Borges in this setting (as there is one of D'Amico [Tribute 25]), but the one at hand features Borges kneeling on the floor in front of a book carousel, looking for a title. So much of the photography of Borges is formal in nature; even the semiformal ones like Stern's image are rather uncommon. However, Facio's image is openly informal, and that informality is complemented by the way in which she places the carousel in the left foreground, such that we see the three-tier array of books that dwarfs the smaller figure of Borges on his knees checking the books. As is customary in all of the photographs from

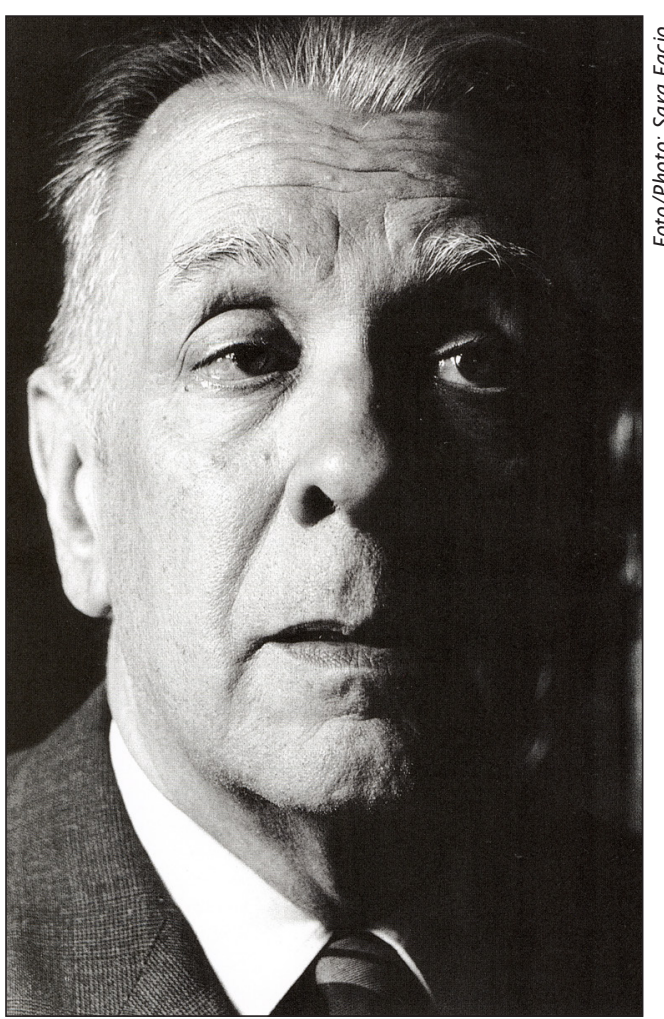

Figura 9.

the 1960s on, Borges is formally dressed in a suit, with a white shirt and tie. In addition, in this case his left lapel sports some sort of pin of merit, which includes a chain running down into the pocket of the suit coat. Both the carousel and the storage closet behind Borges are gorgeous pieces of woodwork, befitting the elegance of the original Biblioteca Nacional on Calle México, dating from the glorious era of the patrician Argentina whose disappearance Borges is often attributed to have lamented. Facio's Borges is totally consumed by the books he is examining, ostensibly unaware of the photographer's presence, by contrast to the enormous bulk of studioposed photographs of the writer. If this is not Stern's humanized Borges or Heinrich's mystical Borges, it is Borges integrated into the world of his most distinguished professional appointment, that of Director of the Biblioteca Nacional.

Finally, I would like to make a brief reference to a photograph that is unquestionably part of an image of Borges late in life. Of course, one could focus here on the many photographs of Borges and Kodama, whose presence at the center of Borges's final years is undoubtedly, in biographical 


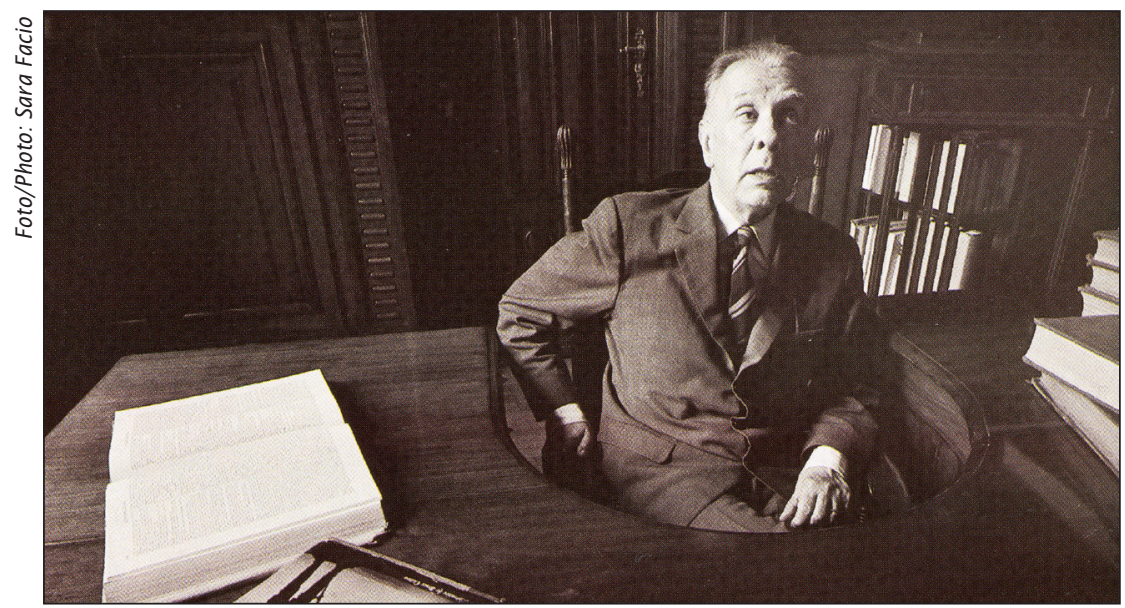

Figura 10.

terms, the most important aspect about them. Yet the image I wish to recall here is by Pepe Fernández. One of the many anecdotal details of Borges's life was his preference for the St. James café, located on Avenida Córdoba a few blocks from his long-time residence on Calle Maipú. One of the many establishments of the city that catered to the "English look," it was where Borges and Norma Thomas DiGiovanni often worked together in the late 1960s and 1970s on the English translations of ten Borges books that were part of Borges's international fame. The St. James subsequently closed and reopened under a new name, and while it still retains much of its old charm, it is now a hang-out a good part of the day for mid-scale prostitutes. In Fernández's photograph, which is undated, Borges sits at a table, dressed much as he is in Facio's photograph, hands resting on what had became his uniquitous cane. He stares off into space before the table set for his tea, oblivious to the gaudily dressed woman behind him, who is decked out in a sequined pants suit whose top just covers her breasts, with mid-thighhigh white leather boots and a white (fake?) fur coat. She holds a cigarette and strikes a pose that Borges's mother would have found reprehensible. I don't know if one could characterize this photograph as cruel. However, it certainly denotes the way in which, by the 1980s, Borges's world had changed foreovere. ${ }^{14}$

I would be remiss in closing this essay without referring, if only very briefly, to photographs of Borges by non-Argentine artists. Of course,

${ }^{14}$ To be sure, prostitutes have always been an integral part of Argentine public life. The point here is that class restrictions kept them out of places like the St. James, the Richmond, the Aguila, the Molina, the Ideal, all in their day the haunts of the Anglophile set with which one side of Borges so identified. 
these abound. In the case of the U.S., Diane Arbus and Richard Avedon are important points of reference. There images can easily be found in the Tribute to Borges volume that contains several of the images I have noted in passing (pages 12 and 13, respectively). Arbus, who often liked to photograph in the outdoors, frames the formally posed Borges (again dressed very much as he is in the Heinrich image, although his business suit appears not to be quite as elegant) framed by a stand of late-fall/ winter trees. Her photograph, as well as Avedon's, has the blind Borges facing the camera, with the result that what dominates-for the American and international public that is always reminded of Borges's blindness and its presumed relationship to the type of literature he writes - is the somewhat frozen look of someone who cannot visually interact with the photographer's camera. By contrast with Arbus's nature setting, Avendon opts for a conventional head and torso shot, and this time, Borges is more elegantly dressed, with a rich textured jacket, a cashmere cardigan, and the by-now commonly sighted lapel pin. Both these American photographers engage in a reverential recording of Borges, befitting the frequent aura of visiting royalty of his American visits.

Today, with the enormous importance Borges has acquired for Latin American and international literary studies, this photographic record of both Argentines and non-Argentine photographers, who became interested in him after Borges achieved international fame, is of significance in understanding the role of photography in Latin American cultural studies, especially as it involves literary figures, and the way in which Borges was seen by the camera in consonance with his evolving role in Argentine letters, from that as a marginal gadfly to the eccentric and perennial nonNobel Prize winner, to that as a premier writer in the Spanish language.

\section{REFERENCES}

FOSTER, David William. "Annemarie Henrich: Photography, Women's Bodies, and Semiotic Excess." Journal of Latin American Popular Culture 25 (2006): 253-70.

FOSTER, David William. Argentine Urban Photography. Jefferson, N.C.: McFarland Publishing, 2007 (forthcoming).

FOSTER, David William. "Dreaming in Feminine: Grete Stern's Photomontages and the Parody of Psychoanalysis." Ciberletras 10 (2003): 10 pages. http://www.lehman.cuny.edu/ ciberletras/v.10/foster.htm

FOSTER, David William. "Sara Facio as Urban Photographer." Foster, Buenos Aires: Perspectives on the City and Cultural Production. Gainesville: UP of Florida, 1998. 170-94. 
FOSTER, David William. "Saudades do Brasil: Claude Lévi-Strauss's Photographic Gaze of the City of São Paulo." Chasqui, special issue no. 3 (2006): 98-125.

HEINRICH, Annemarie. Un cuerpo, una luz, un reflejo. Textos y selección de imágenes, Juan Travnik. Buenos Aires: Ediciones Larivière, 2004.

Image and Memory; Photography from Latin America, 1866-1994: FotoFest. Ed. Wendy Watriss and Lois Parkinson Zamora. Austin: U of Texas P, 1998.

STERNE, Grete. Fotografía en la Argentina, 1937-1981. Buenos Aires: La azotea, Editorial Fotográfica de la Argentina, 1988.

David William Foster Ph. D. (University of Washington) es Regents Professor del Department of Languages and Literatures y Women's Studies en Arizona State University. También es director de Graduate Studies e Interdisciplinary Humanities. Ha publicado textos enfocados principalmente en la narrativa y el teatro de la cultura latinoamericana en general. En estos últimos años su enfoque investigativo se ha diversificado todavía más y ha publicado estudios críticos sobre el cine mexicano, argentino y brasileño. También ha investigado la cultura judía y la teoría queer en América Latina. En relación a estos temas ha publicado Gay and Lesbian Themes in Latin American Writing (1991) en la University of Texas Press, y Bodies and Biases: Sexualities in Hispanic Cultures and Literature, con Robert Reiss, en la University of Minnesota Press (1996). Más recientemente ha publicado las siguientes compilaciones: Sexual Textualities: Essays on Queer/ing Latin American Writing (1997), Chicano/Latino homoerotic identities (1999) Mexico City in Contemporary Mexican Cinema (2002) y Queer Issues in Contemporary Latin American Cinema (2003). 